石油技術協会誌 第 72 巻 第 5 号 (平成 19 年 9 月)

JOURNAL OF THE JAPANESE ASSOCIATION FOR PETROLEUM TECHNOLOGY

VOL. 72, NO. 5 (Sept., 2007)

\author{
講 演 \\ 大陸棚画定に向けた科学的調査 \\ 一大規模 $2 \mathrm{D}$ 地震探査 $-{ }^{*}$ \\ 加 藤 幸 弘 ${ }^{* *}$
}

(Received July 23, 2007 ; accepted August 8, 2007)

\title{
Scientific survey for delineating the outer limits of the extended continental shelf : Long 2D seismic survey
}

Yukihiro Kato

\begin{abstract}
Under the United Nations Convention on the Law of the Sea (UNCLOS), coastal states shall establish the outer limits of continental shelf beyond 200 nautical miles when coastal states fulfill a number of geomorphological and geological criteria. Coastal states must submit information including scientific data defining the outer limits of the continental shelf to the UN Commission on the Limits of the Continental Shelf (CLCS). To prepare the necessary information by the time limit for Japan, exploration of crustal structure which is coincident with wide-angle and multi-channel seismic reflection survey has been conducted under the coordination of an interministerial council.
\end{abstract}

Key words : UNCLOS, continental shelf, long 2D seismic survey

\section{1. はじめに}

現在, 我が国では, 国連海洋法条約の規定に基づいて, 領海基線から 200 海里を超える大陸棚の申請の準備を内 閣官房の調整の下, 関係省庁が連携して行っている。こ の小文では，条約が規定する大陸棚の定義，申請を準備 するのに必要な科学的調査の内容, 各国の申請状況, そ して現在行われている大陸棚調査のうち，特に大規模な $2 \mathrm{D}$ 地震探査について紹介する。

\section{2. 国連海洋法条約に規定される大陸棚}

特段境界が存在しない海洋について, 1982 年に採択 され，1994 年に発効した国連海洋法条約は，主に領海 基線からの位置関係に基づき，沿岸国の権利が異なるい くつかの領域を規定している。以下に述べる大陸棚は,

*平成 19 年 6 月 5 日, 平成 19 年度石油技術協会春季講演会の 特別講演会にて講演 This Special lecture was delivered at the 2007 JAPT annual meeting held in Tokyo, Japan, June 5, 2007.

**海上保安庁海洋情報部 Hydrographic and Oceanographic Department, Japan Coast Guard

Copyright C 2007, JAPT
条約第 76 条で規定されている領域の 1 つであり, 海岸 線と大陸斜面の頂部（大陸棚外縁，通常 $130 \sim 140 \mathrm{~m}$ ) の間で, 極めて緩傾斜の海底と定義される（地学団体研 究会, 1996）地形学における本来の大陸棚とは異なる法 的な定義が与えられ, その範囲も大きく異なることに留 意する必要がある。条約第 76 条では, 大陸棚は「当該 沿岸国の領海を越える海面下の区域の海底及びその下で あってその領土の自然延長をたどって大陸棚縁辺部の外 縁に至るまでのもの又は, 大陸縁辺部の外縁が領海の幅 を測定するための基線から 200 海里の距離まで延びてい ない場合には, 当該沿岸国の領海を越える海面下の区域 の海底及びその下であって当該基線から 200 海里の距離 までのものをいう。」規定し, また, 第 77 条で, 沿岸 国が，「海底及びその下の天然資源（鉱物その他の非生 物資源並びに定着性の種族に属する生物）の探査, 開発 を行う主権的権利」を有する領域としている。沿岸国が 第 76 条の規定に従い, 200 海里を超えて大陸棚の範囲 を獲得するには, 条約によって設置された「大陸棚の限 界に関する委員会」に対して，200海里を超えて大陸棚 が延びていることを示す科学的デー夕を添えて申請を行 


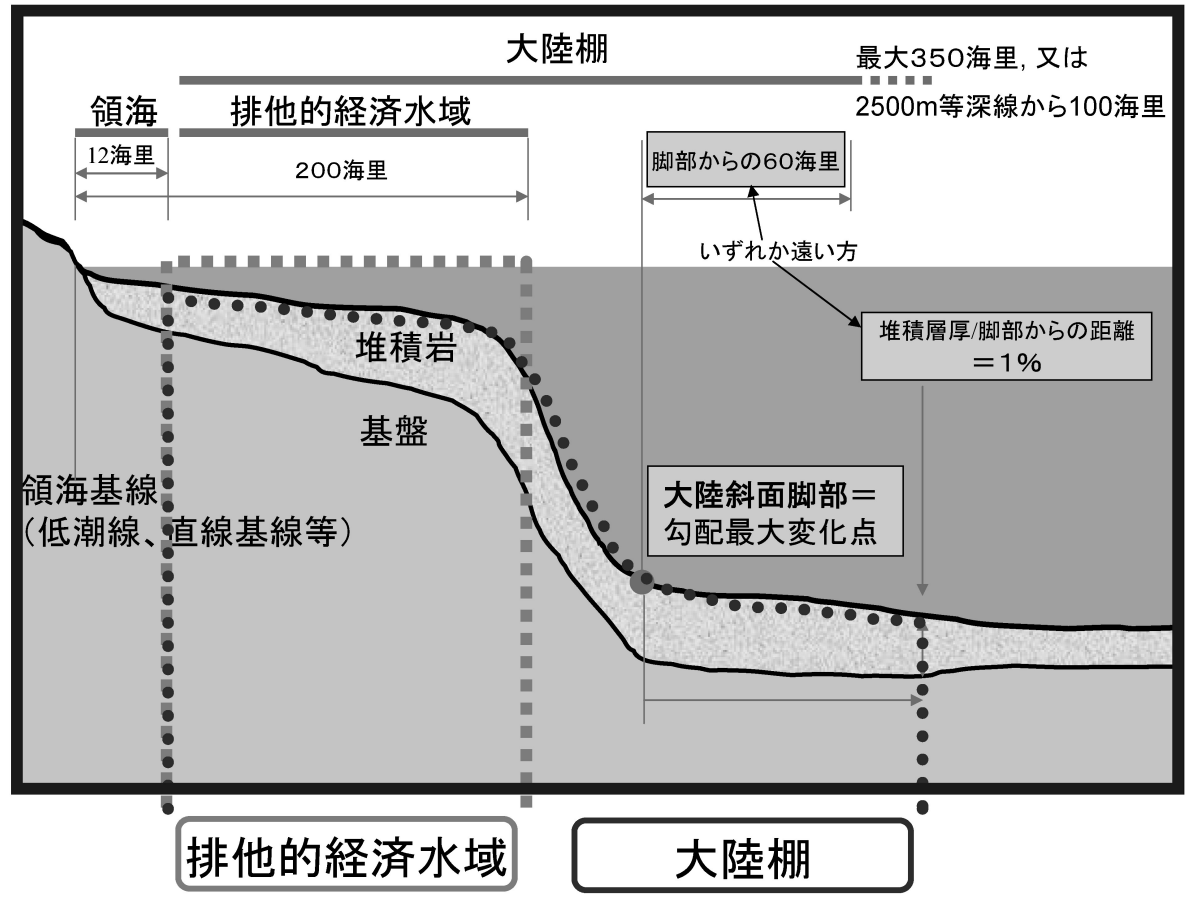

図 1 国連海洋法条約第 76 条に規定される大陸棚

い，審査を受け，そして同委員会の勧告を得る必要があ る。なお，沿岸国は，条約が当該国に発効後，10 年以 内に申請を行う必要があり，我が国の場合，申請の期限 は 2009 年（平成 21 年） 5 月となっている。大陸棚は, 上 記のプロセスを経て初めて 200 海里を超える設定が可能 となる点が，原則として領海基線からの位置関係によつ て，範囲が決定する領海や排他的経済水域とは異なる。 したがって,このプロセスを実行するためには, 条約,「大 陸棚の限界に関する委員会の科学的・技術的ガイドライ ン」の規定に基づき，根拠となる科学的データの収得を 行い, そして, それらのデータを解析, 整理し, 根拠デー 夕に基づく申請の内容が明確な提出情報の作成など一連 の膨大な作業に取り組む必要がある。

\section{3. 大陸棚の外側の境界の画定}

国連海洋法条約の第 76 条には，200 海里を超えて大 陸棚の外縁を設定する規則が， $4 \sim 7$ 項に規定されてい る。この規定にしたがって大陸棚の外側の境界の位置を 画定する手順は，「大陸棚の限界に関する委員会の科学 的および技術的ガイドライン」に以下のように規定され ている。

1）従物性のテストを行う。

大陸縁辺部の外側の境界が，領海の幅を測定する ための基線から 200 海里を超えて延びていること
を示す。

2）大陸斜面の脚部を決定する。(下記のいずれかの方 法)

（a）大陸斜面の基部における傾斜の最大変化点

（b）一般的な規則に対する反証を用いる

3）定則の適応。下記のいずれか遠い方を採用する。

（a）堆積物の厚さが大陸斜面の脚部へ距離の $1 \%$ 以上の点

（b）大陸斜面の脚部から 60 海里を超えない点

4）海底の高まり，海底海嶺の認定を行う。

5）制限の適応。下記のいずれか遠い方までで制限さ れる。

（a）領海基線から 350 海里（海底海嶺は本制限の みが適応となる）

(b) $2,500 \mathrm{~m}$ 等深線から 100 海里

6）大陸棚の外側の限界線を経緯度によって定める 点を結ぶ 60 海里を超えない長さの直線によって 引く。

上記の手順で画定した大陸棚の外側の限界線が, 条約 やガイドラインの規定に適合していることを示すために は，海洋法条約第 76 条および「大陸棚の限界に関する 委員会 科学的・技術的ガイドライン」の規定, 記述と 整合している必要があるのは当然であるが，それ以前に 重要なのは，限界線の線引きを行う上での前提となる考 
え方, つまりどの海底地形までが大陸縁辺部として連続 しているか?さらに，当該大陸縁辺部がどれだけ広がつ ているのか? について客観性を有する科学的デー夕を根 拠として説明することであろう。

これを説明するに当たっては, 基点となる領土から, その自然延長の大陸縁辺部である海底地形について, 地 形の詳細, 構成する地質, 地殼構造などの地球科学的な データの役割が大きい。例えば伊豆・小笠原・マリアナ 弧のような海洋島を頂部とする海底地形は, 周辺の海盆 底, 例えば東方の北西太平洋海盆からは, $6,000 \mathrm{~m}$ 以上, 西方の四国海盆およびパレスベラ海盆からは, 4,500 m 以上の比高を有する巨大な海底山脈であることを，詳 細な海底地形データから説明し，さらに，その海底山脈 が，一連の島弧システムであることを地殼構造のデータ や構成する岩石の種類, 年代データから説明することが 重要である。

もちろん，根拠として使用した調査データ（水深，地 磁気, 重力, 地震探査, 地質など）については, それら が客観性を担保するための詳細な技術的情報が「科学的・ 技術的ガイドライン」では要求されている。例えば，水 深データの技術情報としては以下の技術情報の記述が必 要とされている。

・データの出所

・音響測深技術およびその技術情報

・測位方法およびその座標系

・調査日時

・水中音速に関してデータに施した補正，較正

・ランダム誤差および系統的誤差の先験的な推定

・上記の事後の推定

・測位系など

\section{4. 他国の申請状況}

国連海洋法条約の規定に基づき，領海基線から 200 海 里を超える大陸棚の申請を「大陸棚の限界に関する委員 会」に行おうとする沿岸国は，前述した「科学的・技術 的ガイドライン」に記述された手順にしたがって提出情 報を準備することとなる。しかし，世界の海岸から深海 底に至る海底は，その場所におけるテクトニクスや地史 によってさまざまな地形・地質から構成され，条約やガ イドラインの規定のみから大陸棚の限界を機械的に決め ることはほとんど不可能に近いことが多い。そのため, 大陸棚の申請を行おうとする沿岸国は，委員会がどの範 囲までを大陸棚であると考えるかについて，条約やガイ ドラインの規定の分析のほか, 委員会が他国の申請に対 して行った勧告内容を分析することによって，理解しよ うとしている。以上の観点から，大陸棚の申請を行う沿
岸国にとって, 自国の近傍でなく, 地理的に離れた沿岸 国の申請であっても, その申請内容, 勧告の内容につい て注視することが重要となっている。

2007 年 7 月の時点において, 大陸棚の延長申請を行つ ているのは，ロシア (2001 年 12 月), ブラジル (2004 年 5 月), オーストラリア (2004 年 11 月), アイルラン ド (2005 年 5 月), ニュージーランド (2006 年 4 月), 4 カ国共同 (フランス, アイルランド, スペイン,イギリス) (2006 年 5 月), ノルウェー (2006 年 11 月), フランス (2007 年 5 月）の 7 力国の申請と 4 力国による共同申請の計 8 申請にすぎない。現在の申請数は, 国連海洋法条約の交 渉時において推定された 200 海里を超える大陸棚を持つ 可能性のある国の数, 33 と比べても著しく少ない。

すでに行われた申請のうち，2002 年には，ロシアに 対して, 他国との関係を調整すること, および提出情 報が不十分であるので再提出することとの勧告がなされ た。その後, しばらく勧告は出されなかつたが, 今年 $(2007$ 年） 4 月に，ブラジルおよびアイルランドに対し，大陸 棚の外側の境界についての勧告を初めて行つた。ただし， その勧告内容は公開されておらず，委員会がどのような 基準で審査を行つたのかについての情報は, 現時点にお いても不明である。そのほかの申請については, 現在も 審査が行われている途中であり, 今後, 2009 年に向けて, 申請国が急速に増えることが予測され，その結果として 「大陸棚に関する委員会」の勧告も増加し, その内容が 何らかの形で申請を考える沿岸国に公表され, 大陸棚の 範囲について今後委員会の解釈が明確化されることが期 待される。

一方, 我が国にとっては, インド・オーストラリアプ レートと太平洋プレートとの収束境界に位置し, 背弧海 盆が付随するトンガ・ケルマディック島弧一海溝系が含 まれるニュージーランドの申請, あるいは, 海洋島を基 点として大陸棚の延長を主張するケルゲレン海台やマッ コリー海嶺が含まれるオーストラリアの申請において, 大陸棚についてどのような勧告がなされるかが注目さ れる。

\section{5. 我が国における大陸棚画定に向け た海域調査}

現在, 我が国では大陸棚の申請期限である 2009 年 5 月の期限に向けて，関係省庁が連携して，上記の情報を 整備するために，大規模な海域の調査を行っている。調 査は，精密海底地形調査（マルチビーム測深機による）, 地殼構造探査（反射法地震探査と屈折法地震探査を併用 する)，基盤岩採取（BMS；海底ボーリングによる）の 3 項目である。このうち精密海底地形調査は海上保安庁 
が, 地殼構造探査については海上保安庁と文部科学省 (海 洋研究開発機構（JAMSTEC））が，また，基盤岩採取に ついては経済産業省（石油天然ガス・金属鉱物資源機構 (JOGMEC) および産業技術総合研究所（AIST））が担当 している。

大陸棚画定に向けての調査の内，地殼構造探査では， 我が国では過去例のない密度, 規模で $2 \mathrm{D}$ 反射法と屈折 法地震探査を組み合わせた探査を海上保安庁と海洋研究 開発機構が分担して実施している。このうち, 海上保安 庁は，測量船による探査および民間調査船による探査を 組み合わせ実施している。以下の海上保安庁の地殼構造 探査の仕様の概要を示す（金田他 2005，林田他 2005）。

1） 測量船による地殼構造探査

$2 \mathrm{D}$ 反射法地震探査と屈折法地震探査を同一測線で 実施

（反射法地震探査）

シングルチャンネルおよびマルチチャンネル反射法地 震探査

シングルチャンネル反射法地震探査

エアガン 700 cu.in. (350 cu.in. を 2 台使用)

ストリーマ $1 \mathrm{ch} 65 \mathrm{~m}$

マルチチャンネル反射法地震探査

エアガン $\quad 3,000$ cu.in. (1,500 cu.in. を 2 台使用)

ストリーマ $120 \mathrm{ch}$ (12.5 m 間隔) $3,000 \mathrm{~m}$

(屈折法地震探査)

震源エアガン 6,000 cu.in. (1,500 cu.in. を 4 台使用) 発信間隔 $200 \mathrm{~m}$

OBS 設置間隔 $5 \mathrm{~km}$

2）民間調査船による地殻構造探査

$2 \mathrm{D}$ 反射法地震探査と屈折法地震探査を同一測線で
実施

（反射法地震探査）

マルチチャンネル反射法地震探査

エアガン 8,040 cu.in. (tuned array 36 台使用)

ストリーマ $480 \mathrm{ch}$ (12.5 m 間隔) $6,000 \mathrm{~m}$

(屈折法地震探査)

震源エアガン 8,040 cu.in. (tuned array 36 台使用) 発信間隔 $\quad 200 \mathrm{~m}$

OBS 設置間隔 $5 \mathrm{~km}$

これまで実施された探査によって, 日本南方海域にお ける各種の海底地形, 例えば海山, 海嶺, 背弧海盆など の地殼構造について, 明らかにされつつある. 特に, 北 西太平洋海盆の海洋地殼については, その内部構造が今 までにない精度でイメージングされつつある。これらの 新しい成果は, 海底地形データや基盤岩データと合わせ, 複雑な地形, 地質で構成される我が国南方の大陸縁辺部 について，目的とする，その連続性，その範囲について 明確な情報を与え, 大陸棚の申請に貢献することにとど まらず，同海域における地形，地質の形成過程の理解に つながる重要なデータと成ることが期待される。

\section{引用 文 献}

金田謙太郎・下村広樹・志岐俊郎・小山あずさ・伊藤清 寿, 2005: 南鳥島周辺の屈折法探査〜 2004 年度第 5-7, 10-11 次大陸棚調査～. 海洋情報部技報, $27,8-22$. 林田政和 - 浜本文隆 - 田中喜年 - 松本正純, 2005 ：大東 海嶺群における精密地殼構造探査. 海洋情報部技報, $27,33-45$.

地学団体研究会編, 1996 : 新版地学事典, 755, 平凡社. 